\title{
Salsuginibacillus halophilus sp. nov., a halophilic bacterium isolated from a soda lake
}

\author{
Shu-Juan Cao, Jian-Hang Qu, Hong-Li Yuan and Bao-Zhen Li
}

Correspondence

Hong-Li Yuan

hlyuan@cau.edu.cn
State Key Lab for Agrobiotechnology, Key Laboratory of Agro-Microbial Resource and Application, Ministry of Agriculture, College of Biological Sciences, China Agricultural University, Beijing 100193, PR China

\begin{abstract}
A Gram-stain-positive, rod-shaped, endospore-forming, halophilic, alkalitolerant bacterium, designated halo $-1^{\top}$, was isolated from sediment of Xiarinaoer soda lake, located in the Inner Mongolia Autonomous Region of China. Strain halo- $1^{\top}$ grew in the presence of $9-30 \%(w / v)$ $\mathrm{NaCl}$ (optimum 19\%) and at $\mathrm{pH}$ 5-10 (optimum pH 9). The cell-wall peptidoglycan contained meso-diaminopimelic acid and the major respiratory isoprenoid quinone was MK-7. The predominant cellular fatty acids of the isolate were anteiso- $\mathrm{C}_{15: 0}(58.35 \%)$, anteiso- $\mathrm{C}_{17: 0}$ (12.89\%) and $\mathrm{C}_{16: 0}(6.52 \%)$. The polar lipids contained diphosphatidylglycerol, phosphatidylglycerol, phosphatidylethanolamine, glycolipid and a phospholipid of unknown structure. The DNA G +C content of the strain was $46.4 \mathrm{~mol} \%$. On the basis of $16 \mathrm{~S}$ rRNA gene sequence similarity, strain halo- $1^{\top}$ showed the highest similarity $(93.9 \%)$ to Salsuginibacillus kocurii $\mathrm{CH}_{9} \mathrm{~d}^{\top}$. Strain halo- ${ }^{\top}$ could be clearly differentiated from its closest phylogenetic relative on the basis of several phenotypic, genotypic and chemotaxonomic features. Therefore, strain halo- $1^{\top}$ represents a novel species, for which the name Salsuginibacillus halophilus sp. nov. is proposed, with the type strain halo- $1^{\top}\left(=\right.$ CGMCC $1.7653^{\top}=$ NBRC $\left.104934^{\top}\right)$.
\end{abstract}

Soda lakes represent the most alkaline naturally occurring environments on earth, with $\mathrm{pH}$ values generally greater than 10 , occasionally reaching 12 . These lakes are characterized by the presence of large amounts of $\mathrm{Na}_{2} \mathrm{CO}_{3}$ (usually as $\mathrm{Na}_{2} \mathrm{CO}_{3} \cdot 10 \mathrm{H}_{2} \mathrm{O}$ or $\mathrm{Na}_{2} \mathrm{CO}_{3} \cdot \mathrm{NaHCO}_{3} \cdot 2 \mathrm{H}_{2} \mathrm{O}$ ) and depletion of $\mathrm{Mg}^{2+}$ and $\mathrm{Ca}^{2+}$ because of the insolubility of these cations as carbonate minerals under alkaline conditions. Such lakes are also somewhat saline, due to the concomitant increase in $\mathrm{Cl}^{-}$(Duckworth et al., 1996).

In order to investigate alkaliphilic and halophilic bacteria, we isolated some strains from sediment of Xiarinaoer soda lake, which is located in Inner Mongolia, China. The sample was collected in March 2006 and the temperature was $-1{ }^{\circ} \mathrm{C}$, the $\mathrm{pH}$ was 9.91 and the salinity of the water was $84 \mathrm{~g} \mathrm{NaCl} \mathrm{l}^{-1}$ at the time of sampling. The sediment was suspended in liquid base complex medium and vortexed for about $1 \mathrm{~min}$. The suspension was allowed to settle, serially diluted with liquid medium and spread on plates of the base complex medium. The base complex medium for isolation and maintenance contained $7.5 \mathrm{~g}$ casein hydrolysate, 10 g yeast extract (Difco), $3 \mathrm{~g}$ sodium citrate, $2 \mathrm{~g} \mathrm{KCl}$, a trace amount of $\mathrm{FeSO}_{4}, 200 \mathrm{~g} \mathrm{NaCl}$ and

The GenBank/EMBL/DDBJ accession number for the $16 \mathrm{~S}$ rRNA gene sequence of strain halo- $1^{\top}$ is EU581835.

Maximum-parsimony and minimum-evolution 16S rRNA gene sequence-based phylogenetic trees are available as supplementary material with the online version of this paper.
$10 \mathrm{~g} \mathrm{Na}_{2} \mathrm{CO}_{3}$ in $1 \mathrm{l}$ distilled water. If required, the medium was solidified by adding agar $\left(18 \mathrm{~g} \mathrm{l}^{-1}\right)$ (Pan et al., 2006). The $\mathrm{pH}$ was adjusted to 9 with $30 \%$ (w/v) $\mathrm{Na}_{2} \mathrm{CO}_{3}$ solution and plates were incubated at $37{ }^{\circ} \mathrm{C}$ for 1 week. The reference type strain Salsuginibacillus kocurii DSM $18087^{\mathrm{T}}$ was grown using the medium and conditions reported by Carrasco et al. (2007).

A $16 \mathrm{~S}$ rRNA gene fragment from strain halo- $1^{\mathrm{T}}$ was amplified using individual bacterial colony PCR (Güssow \& Clackson, 1989). The primers used for PCR were 27F (5'-GAGAGTTTGATCCTGGCTCAG) and 1495R (5'CTACGGCTACCTTGTTACGA) (covering positions 271495 in the Escherichia coli numbering system; Brosius et al., 1978). PCR products were sequenced using an Applied Biosystems DNA Sequencer 3730 with the software provided by the manufacturer. An almost-complete 16S rRNA gene sequence of strain halo- $1^{\mathrm{T}}(1438 \mathrm{bp})$ was initially compared with reference sequences in the GenBank database using BLAST (Altschul et al., 1997).

Alignments of sequences were carried out using CLUSTAL W version 1.8 (Thompson et al., 1994). Similarity was calculated by the method of Jukes \& Cantor (1969) in the CLUSTAL W program. Phylogenetic analysis of multiple sequence alignments was performed with software MEGA version 3.1 (Kumar et al., 2004). Phylogenetic tree reconstruction was carried out by the neighbour-joining (Saitou \& Nei, 1987), minimum-evolution (Rzhetsky \& Nei, 1993) and maximumparsimony (Kluge \& Farris, 1969) methods. 
With respect to $16 \mathrm{~S}$ rRNA gene sequence similarity, strain halo- $1^{\mathrm{T}}$ was most closely related to Salsuginibacillus kocurii CH9d $\mathrm{d}^{\mathrm{T}}$ (93.9\%); similarity to members of other genera was lower than $92 \%$. These rather low levels of sequence similarity suggest that strain halo- $1^{\mathrm{T}}$ belongs to a novel taxonomic group.

The phylogenetic analysis showed that strain halo- $1^{\mathrm{T}}$ belonged to the Firmicutes. It formed a phyletic branch with S. kocurii $\mathrm{CH}_{9} \mathrm{~d}^{\mathrm{T}}$ in the neighbour-joining analysis (Fig. 1). Phylogenetic trees constructed using the minimum-evolution and maximum-parsimony methods gave topologies similar to that of the neighbour-joining tree (Supplementary Fig. S1, available in IJSEM Online).

To characterize strain halo- $1^{\mathrm{T}}$ phenotypically, standard phenotypic tests were performed on both strain halo- $1^{\mathrm{T}}$ and its closest neighbour S. kocurii DSM $18087^{\mathrm{T}}$ using the alkaline, saline medium described by Carrasco et al. (2007); the concentration of $\mathrm{NaCl}$ was adjusted to $19 \%$ for growth of strain halo- $1^{\mathrm{T}}$. Gram staining was performed using the method described by Dussault (1955). To determine cell morphology, bacterial cultures grown on plates for about 2 days at $37^{\circ} \mathrm{C}$ were stained using crystal violet and then examined by microscopy. Motility was tested using the alkaline, saline medium using plates containing $0.15 \%$ agar; the occurrence of diffuse growth along the stab line in the medium was observed. Spore formation was tested using cultures grown for 3 weeks on alkaline, saline medium with $\mathrm{CaCl}_{2}(1 \mathrm{mM}), \mathrm{MnCl}_{2}(50 \mathrm{nM})$ and $\mathrm{MgCl}_{2}$ $(1 \mathrm{mM})$ added. Colony morphology was observed after 2 days of incubation on solid alkaline, saline medium. Growth at different concentrations of $\mathrm{NaCl}$ was determined in liquid alkaline, saline medium with 0 and $1-30 \%$ $(\mathrm{w} / \mathrm{v}) \mathrm{NaCl}$ (in increments of $2 \%$ ). The $\mathrm{pH}$ for growth was tested in liquid medium at $\mathrm{pH}$ 5.0-13.0 (in increments of

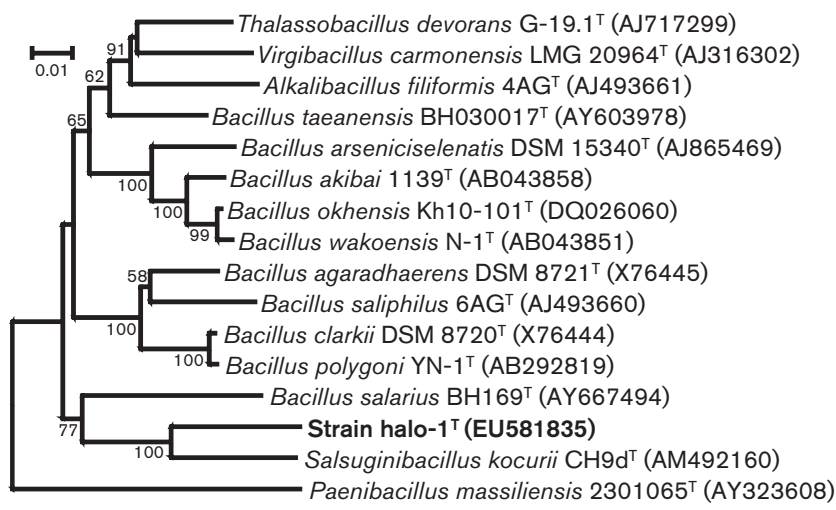

Fig. 1. Neighbour-joining tree showing the phylogenetic position of strain halo- $1^{\top}, S$. kocurii $\mathrm{CH}^{\top} \mathrm{d}^{\top}$ and other reference strains based on 16S rRNA gene sequences. The sequence of Paenibacillus massiliensis $2301065^{\top}$ was used as an outgroup. Bootstrap values expressed as percentages of 1000 replications are shown at branch points when greater than $50 \%$. Bar, 0.01 substitutions per nucleotide position.
$0.5 \mathrm{pH}$ units) adjusted with $30 \%(\mathrm{w} / \mathrm{v}) \mathrm{Na}_{2} \mathrm{CO}_{3}$ solution. The temperature range for growth was determined by incubation in the same liquid medium for 1 day to 3 weeks at $4,18,28,37$ and $50{ }^{\circ} \mathrm{C}$. Growth was scored as $\mathrm{OD}_{600}$. The catalase reaction was performed by placing a small amount of the culture incubated for $24 \mathrm{~h}$ on a slide and adding a drop of $3 \% \mathrm{H}_{2} \mathrm{O}_{2}$ solution. The presence of gas bubbles indicated a positive reaction. Oxidase was examined by daubing cultures incubated for $24 \mathrm{~h}$ on filter paper soaked with $N, N$-dimethyl $p$-phenylenediamine solution; the appearance of a red colour within $10 \mathrm{~s}$ indicated a positive reaction. Utilization of carbohydrates was assessed using liquid medium containing $2.0 \mathrm{~g}$ $\left(\mathrm{NH}_{4}\right)_{2} \mathrm{SO}_{4}, 0.5 \mathrm{~g} \mathrm{NaH}_{2} \mathrm{PO}_{4}, 0.5 \mathrm{~g} \mathrm{~K}_{2} \mathrm{HPO}_{4}, 0.2 \mathrm{~g} \mathrm{MgSO}_{4}$, $0.02 \%(\mathrm{w} / \mathrm{v})$ yeast extract and $19 \%(\mathrm{w} / \mathrm{v}) \mathrm{NaCl}$ for halo- $1^{\mathrm{T}}$ or $10 \%(\mathrm{w} / \mathrm{v}) \mathrm{NaCl}$ for S. kocurii DSM $18087^{\mathrm{T}}$, with the tested carbohydrate at $0.5 \%(\mathrm{w} / \mathrm{v})$, in 11 distilled water; the $\mathrm{pH}$ was adjusted to 9.0 . Incubation was at $37^{\circ} \mathrm{C}$, and the result was determined spectrophotometrically by measuring the $\mathrm{OD}_{600}$ after 3 days. Other tests including aesculin hydrolysis, phenylalanine deaminase, antibiotic sensitivity and other tests listed in Table 1 and the species description were performed according the methods described by Dong \& Cai (2001); S. kocurii DSM $18087^{\mathrm{T}}$ was also tested as a control.

Cell mass for quinone, cellular fatty acid and cell-wall peptidoglycan analyses was obtained from a culture grown in base complex medium at $37^{\circ} \mathrm{C}, \mathrm{pH} 9.0$ and the appropriate optimal $\mathrm{NaCl}$ concentration. For analysis of isoprenoid quinones, cells grown aerobically were freezedried and subjected to extraction of the lipid fraction as described by Collins (1985). For quantitative analysis of cellular fatty acids, fatty acid methyl ester mixtures were prepared and identified following the manufacturer's instructions for the Microbial Identification System (MIDI Inc.); fatty acids were identified and quantified by the Sherlock MIS software (version 4.5). The type of cellwall peptidoglycan was determined by TLC (Hasegawa et al., 1983). For polar lipid analyses, cell biomass of strain halo- $1^{\mathrm{T}}$ and S. kocurii DSM $18087^{\mathrm{T}}$ was obtained from cultures grown in alkaline, saline medium at $37{ }^{\circ} \mathrm{C}$ for $24 \mathrm{~h}$. Lipids were extracted according to the method of Bligh \& Dyer (1959). Polar lipids were analysed by twodimensional TLC on silica gel plates (Merck) (Minnikin et al., 1977).

Genomic DNA was prepared according to the method of Marmur (1961). The $\mathrm{G}+\mathrm{C}$ content was analysed by the thermal denaturation method using a BIO-20 UV spectrophotometer according to De Ley et al. (1970). For the calculation of DNA G + C content, the equation of De Ley et al. (1970) was used and corrected using genomic DNA of Escherichia coli $\mathrm{K}-12$ as a reference.

Cells of strain halo- $1^{\mathrm{T}}$ were Gram-stain-positive, aerobic, non-motile straight rods. The oxidase reaction was negative and the catalase reaction was positive. Colonies grown on alkaline, saline agar medium were round, 
Table 1. Characteristics that distinguish strain halo- $1^{\top}$ from $S$. kocurii $\mathrm{CH} \mathrm{d}^{\top}$

Data for S. kocurii CH9d ${ }^{\mathrm{T}}$ were taken from Carrasco et al. (2007) unless indicated.

\begin{tabular}{|c|c|c|}
\hline Characteristic & Strain halo-1 ${ }^{\mathrm{T}}$ & S. kocurii CH9d ${ }^{\mathrm{T}}$ \\
\hline Colony pigmentation & Yellow & Cream \\
\hline \multicolumn{3}{|l|}{$\mathrm{NaCl}$ concentration for growth $(\%, \mathrm{w} / \mathrm{v})$} \\
\hline Range & $9-30$ & $3-20$ \\
\hline Optimum & 19 & 10 \\
\hline \multicolumn{3}{|l|}{$\mathrm{pH}$ for growth } \\
\hline Range & $5.0-10.0$ & $5.8-10.0$ \\
\hline Optimum & 9.0 & 8.5 \\
\hline Urease & + & $-{ }^{*}$ \\
\hline $\mathrm{H}_{2} \mathrm{~S}$ production & + & - \\
\hline \multicolumn{3}{|l|}{ Hydrolysis of: } \\
\hline Gelatin & + & - \\
\hline Aesculin & - & $+\dagger$ \\
\hline DNA G $+\mathrm{C}$ content $(\mathrm{mol} \%)$ & 46.4 & 44.7 \\
\hline \multicolumn{3}{|l|}{ Utilization of: } \\
\hline Lactose, maltose, D-salicin, trehalose, glycerol, & + & - \\
\hline D-sorbitol, inositol & & \\
\hline D-Ribose & - & + \\
\hline \multicolumn{3}{|l|}{ Sensitivity to: } \\
\hline Tetracycline & - & + \\
\hline Kanamycin & + & - \\
\hline
\end{tabular}

${ }^{*}$ Data from this study.

$\dagger$ Data from this study; reported as negative by Carrasco et al. (2007).

convex, entire, yellow and semi-transparent, $1-2 \mathrm{~mm}$ in diameter after 2 days of incubation at $37^{\circ} \mathrm{C}$. Spores were present in a central position. Strain halo- $1^{\mathrm{T}}$ was extremely halophilic and alkalitolerant. It grew in media containing 9-30\% (w/v) $\mathrm{NaCl}$ and optimally at $19 \%(\mathrm{w} / \mathrm{v}) \mathrm{NaCl}$. The strain could not grow without $\mathrm{NaCl}$. The $\mathrm{pH}$ range for growth was 5.0-10.0 (optimum $\mathrm{pH} 9.0$ ). For S. kocurii DSM $18087^{\mathrm{T}}$, the range of $\mathrm{NaCl}$ concentration for growth was 3-20\% (w/v) $\mathrm{NaCl}$ and optimal growth was observed at $10 \%(\mathrm{w} / \mathrm{v}) . \mathrm{H}_{2} \mathrm{~S}$ was produced by strain halo- $1^{\mathrm{T}}$, but not by $S$. kocurii DSM $18087^{\mathrm{T}}$. Hydrolysis of gelatin was positive for strain halo- $1^{\mathrm{T}}$ but negative for S. kocurii DSM $18087^{\mathrm{T}}$. S. kocurii DSM $18087^{\mathrm{T}}$ could hydrolysis aesculin but strain halo- $1^{\mathrm{T}}$ could not. Detailed morphological and physiological characteristics are given in the species description and Table 1.

The major fatty acids of strain halo- ${ }^{\mathrm{T}}$ were anteiso- $\mathrm{C}_{15: 0}$ $(58.35 \%)$ and anteiso- $\mathrm{C}_{17: 0}(12.89 \%)$, similar to S. kocurii DSM $18087^{\mathrm{T}}$. The whole-cell fatty acid profile is shown in Table 2. It is possible that the differences between the strains in the proportions of some fatty acids were the result of the different media used for growth. However, the major components are clear. The cell-wall peptidoglycan contained meso-diaminopimelic acid, and predominant menaquinone was MK-7, as for phylogenetically related taxa. The polar lipids of strain halo- $1^{\mathrm{T}}$ contained diphosphatidylglycerol, phosphatidylglycerol, phosphatidyletha- nolamine, glycolipid and a phospholipid of unknown structure. The $\mathrm{G}+\mathrm{C}$ content of the genomic DNA of strain halo- $1^{\mathrm{T}}$ was $46.4 \mathrm{~mol} \%$, a little higher than its closest neighbour S. kocurii CH9d $\mathrm{d}^{\mathrm{T}}(44.7 \mathrm{~mol} \%)$. On the basis of the phylogenetic, morphological and physiological characteristics described above, isolate halo- $1^{\mathrm{T}}$ belongs to the genus Salsuginibacillus; however, the low 16S rRNA gene sequence similarity and other differences between halo- $1^{\mathrm{T}}$ and S. kocurii DSM $18087^{\mathrm{T}}$ indicate that strain halo- $1^{\mathrm{T}}$ represents a novel species, for which the name Salsuginibacillus halophilus sp. nov. is proposed.

\section{Description of Salsuginibacillus halophilus sp. nov.}

Salsuginibacillus halophilus (ha.lo.phi'lus. Gr. n. hals salt; Gr. adj. philos loving; N.L. masc. adj. halophilus saltloving).

Cells are Gram-stain-positive, spore-forming, non-motile rods, $0.5-0.8 \times 2.5-4.5 \mu \mathrm{m}$. After $48 \mathrm{~h}$, colonies on agar medium are $1-2 \mathrm{~mm}$ in diameter, round, convex, entire, yellow and semi-transparent. Growth occurs at $18-50{ }^{\circ} \mathrm{C}$ (optimum $37{ }^{\circ} \mathrm{C}$ ). Halophilic; grows at 9-30\% (w/v) $\mathrm{NaCl}$. Can not grow without NaCl; optimal growth at $19 \%(w / v)$ $\mathrm{NaCl}$. The $\mathrm{pH}$ range for growth is 5.0-10.0 (optimum $\mathrm{pH}$ 9.0). Catalase-positive and oxidase-negative. Nitrate is reduced to nitrite. Casein, DNA, Tween 80, starch and aesculin are not hydrolysed; gelatin is clearly hydrolysed. 
Table 2. Cellular fatty acid profiles of strain halo- $1^{\top}$ and $S$. kocurii $\mathrm{CH} 9 \mathrm{~d}^{\top}$

Data for S. kocurii CH9d ${ }^{\mathrm{T}}$ were taken from Carrasco et al. (2007). - , Not detected/not reported. Strain halo- $1^{\mathrm{T}}$ was grown on base agar medium ( $\mathrm{pH}$ 9) prepared following the manufacturer's instructions for the Microbial Identification System (MIDI).

\begin{tabular}{|c|c|c|}
\hline Fatty acid & Strain halo- ${ }^{\mathrm{T}}$ & S. kocurii CH9d ${ }^{\mathrm{T}}$ \\
\hline $\mathrm{C}_{10: 0}$ & 0.05 & - \\
\hline $\mathrm{C}_{12: 0}$ & 0.15 & - \\
\hline iso- $\mathrm{C}_{13: 0}$ & 0.04 & - \\
\hline anteiso- $\mathrm{C}_{13: 0}$ & 0.21 & - \\
\hline iso- $\mathrm{C}_{14: 0}$ & 5.13 & 2.0 \\
\hline $\mathrm{C}_{14: 0}$ & 1.27 & 0.3 \\
\hline Summed feature $1^{\star}$ & 0.34 & - \\
\hline anteiso- $\mathrm{C}_{15: 1} \mathrm{~A}$ & 0.20 & - \\
\hline iso- $\mathrm{C}_{15: 0}$ & 5.28 & 6.9 \\
\hline anteiso- $\mathrm{C}_{15: 0}$ & 58.35 & 49.7 \\
\hline $\mathrm{C}_{15: 0}$ & 0.95 & - \\
\hline iso- $\mathrm{C}_{16: 0}$ & 4.40 & 5.7 \\
\hline Summed feature $3^{*}$ & 0.39 & - \\
\hline $\mathrm{C}_{16: 0}$ & 6.52 & - \\
\hline iso- $\mathrm{C}_{17: 0}$ & 0.54 & 8.0 \\
\hline anteiso- $\mathrm{C}_{17: 0}$ & 12.89 & 16.4 \\
\hline $\mathrm{C}_{17: 0}$ cyclo & 0.11 & - \\
\hline iso- $\mathrm{C}_{17: 1} \omega 5 c$ & - & 1.8 \\
\hline $\mathrm{C}_{17: 0}$ & 0.24 & - \\
\hline anteiso- $\mathrm{C}_{17: 1}$ & - & 1.6 \\
\hline $\mathrm{C}_{18: 1} \omega 9 c$ & 0.68 & - \\
\hline $\mathrm{C}_{18: 1} \omega 7 c$ & 0.57 & - \\
\hline $\mathrm{C}_{18: 1} \omega 5 c$ & 0.31 & - \\
\hline $\mathrm{C}_{18: 0}$ & 1.27 & - \\
\hline iso- $\mathrm{C}_{18: 0}$ & - & 0.23 \\
\hline $\mathrm{C}_{19: 0}$ cyclo $\omega 8 \mathrm{c}$ & 0.11 & - \\
\hline
\end{tabular}

* Summed features are combinations of fatty acids that cannot be separated by the MIDI system. Summed feature 1 comprises iso- $\mathrm{C}_{15: 1}$ $\mathrm{H}$ and/or $\mathrm{C}_{13: 0} 3-\mathrm{OH}$; summed feature 3 comprises iso- $\mathrm{C}_{15: 0} 2-\mathrm{OH}$ and/or $\mathrm{C}_{16: 1} \omega 7 c$.

$\mathrm{H}_{2} \mathrm{~S}$ is produced. Indole is not detected. Urease test is positive. Phenylalanine deaminase-negative. The following carbohydrates can be used as sole carbon sources: Dglucose, cellobiose, lactose, maltose, sucrose, D-salicin, trehalose, D-mannitol, glycerol, L-rhamnose, D-sorbitol and inositol. D-Ribose, D-fructose, D-galactose, D-mannose, raffinose, starch, sodium gluconate, D- and L-arabinose, D-xylose, melezitose and inulin are not fermented. Resistant to chloramphenicol (30 $\mu \mathrm{g}$ per disc), ampicillin $(10 \mu \mathrm{g})$, tetracycline $(30 \mu \mathrm{g})$ and carbenicillin $(100 \mu \mathrm{g})$ and sensitive to streptomycin $(10 \mu \mathrm{g})$ and kanamycin $(30 \mu \mathrm{g})$. Major cellular fatty acids are anteiso- $\mathrm{C}_{15: 0}$ and anteiso- $\mathrm{C}_{17: 0}$. Cell-wall peptidoglycan contains mesodiaminopimelic acid. Polar lipids include diphosphatidylglycerol, phosphatidylglycerol, phosphatidylethanolamine, glycolipid and a phospholipid of unknown structure.
Predominant respiratory quinone is MK-7. The DNA $\mathrm{G}+\mathrm{C}$ content of the type strain is $46.4 \mathrm{~mol} \%$.

The type strain, halo- ${ }^{\mathrm{T}} \quad\left(=\mathrm{CGMCC} 1.7653^{\mathrm{T}}=\mathrm{NBRC}\right.$ $104934^{\mathrm{T}}$ ), was isolated from sediment of Xiarinaoer soda lake in Inner Mongolia, China.

\section{Acknowledgements}

This work was supported by the project from the Chinese National Natural Science Foundation (no. 30670071), the Special Program for Water Pollution Control of Taihu Lake in Jiangsu Province, China (no. BK2007741), and the China Postdoctoral Science Foundation (no. 20070420432).

\section{References}

Altschul, S. F., Madden, T., Schäffer, A. A., Zhang, J., Zhang, Z., Miller, W. \& Lipman, D. J. (1997). Gapped BLAST and PSI-BLAST: a new generation of protein database search programs. Nucleic Acids Res 25, 3389-3402.

Bligh, E. G. \& Dyer, W. J. (1959). A rapid method of total lipid extraction and purification. Can J Biochem Physiol 37, 911-917.

Brosius, J., Palmer, J. L., Kennedy, J. P. \& Noller, H. F. (1978). Complete nucleotide sequence of a $16 \mathrm{~S}$ ribosomal RNA gene from Escherichia coli. Proc Natl Acad Sci U S A 75, 4801-4805.

Carrasco, I. J., Márquez, M. C., Xue, Y., Ma, Y., Cowan, D. A., Jones, B. E., Grant, W. D. \& Ventosa, A. (2007). Salsuginibacillus kocurii gen. nov., sp. nov., a moderately halophilic bacterium from soda-lake sediment. Int J Syst Evol Microbiol 57, 2381-2386.

Collins, M. D. (1985). Isoprenoid quinone analysis in classification and identification. In Chemical Methods in Bacterial Systematics, pp. 267-287. Edited by M. Goodfellow \& D. E. Minnikin. London: Academic Press.

De Ley, J., Cattoir, H. \& Reynaerts, A. (1970). The quantitative measurement of DNA hybridization from renaturation rates. Eur $J$ Biochem 12, 133-142.

Dong, X.-Z. \& Cai, M.-Y. (editors) (2001). Determination of biochemical properties. In Manual for the Systematic Identification of General Bacteria, pp. 370-398. Beijing: Science Press (in Chinese).

Duckworth, A. W., Grant, W. D., Jones, B. E. \& van Steenbergen, R. (1996). Phylogenetic diversity of soda lake alkaliphiles. FEMS Microbiol Ecol 19, 181-191.

Dussault, H. P. (1955). An improved technique for staining red halophilic bacteria. J Bacteriol 70, 484-485.

Güssow, D. \& Clackson, T. (1989). Direct clone characterization from plaques and colonies by the polymerase chain reaction. Nucleic Acids Res 17, 4000.

Hasegawa, T., Takizawa, M. \& Tanida, S. (1983). A rapid analysis for chemical grouping of aerobic actinomycetes. J Gen Appl Microbiol 29, 319-322.

Jukes, T. H. \& Cantor, C. R. (1969). Evolution of protein molecules. In Mammalian Protein Metabolism, vol. 3, pp. 21-132. Edited by H. N. Munro. New York: Academic Press.

Kluge, A. G. \& Farris, J. S. (1969). Quantitative phyletics and the evolution of anurans. Syst Zool 18, 1-32.

Kumar, S., Tamura, K. \& Nei, M. (2004). MEGA3: integrated software for molecular evolutionary genetics analysis and sequence alignment. Brief Bioinform 5, 150-163. 
Marmur, J. (1961). A procedure for the isolation of deoxyribonucleic acid from microorganisms. J Mol Biol 3, 208-218.

Minnikin, D. E., Patel, P. V., Alshamaony, L. \& Goodfellow, M. (1977). Polar lipid composition in the classification of Nocardia and related bacteria. Int J Syst Bacteriol 27, 104-117.

Pan, H.-L., Zhou, C., Wang, H.-L., Xue, Y.-F. \& Ma, Y.-H. (2006). Diversity of halophilic archaea in hypersaline lakes of Inner Mongolia, China. Wei Sheng Wu Xue Bao 46, 1-6 (in Chinese).
Rzhetsky, A. \& Nei, M. (1993). Theoretical foundation of the minimum-evolution methods of phylogenetic inference. Mol Biol Evol 10, 1073-1095.

Saitou, N. \& Nei, M. (1987). The neighbor-joining method: a new method for reconstructing phylogenetic trees. Mol Biol Evol 4, 406-425.

Thompson, J. D., Higgins, D. G. \& Gibson, T. J. (1994). ClustAL W: improving the sensitivity of progressive multiple sequence alignment through sequence weighting, position-specific gap penalties and weight matrix choice. Nucleic Acids Res 22, 4673-4680. 